\title{
Last planner system in construction
}

\author{
Katarzyna Ćwik ${ }^{1}$ Jerzy Rosłon ${ }^{1 *}$ \\ ${ }^{1}$ Warsaw University of Technology, Civil Engineering Faculty, Armii Ludowej 16, 00-637 Warsaw, \\ Poland
}

\begin{abstract}
The paper presents the set of information on the particular measures of the Last Planner System (LPS) of Production Control. Then, the system as a whole is described and the profits for all relevant parties of investment process arising from adopting the Last Planner System are shown. Paper include comparison between LPS and traditional project control model.
\end{abstract}

\section{Introduction}

According to data presented by Lean Construction Institute, at the moment even $70 \%$ of the projects are over budget and delivered late [10]. The situation in building industry is getting worse every year - the results achieved in construction section are far less efficient than the ones obtained by remaining branches like Education, Health and Social Care, Transportation and Information.

Numerous attempts have been made in order to find a solution for the current inefficiency of building industry [5, 6, 7]. Here comes the solution - Last Planner System of Production Control as a tool developed by Hermann Glenn Ballard since 1992.

In the beginning, the specific attention has been paid to achieving better results in weekly work plans. Then, the lookahead process has been added to control the work flow better. Eventually, the scope of Last Planner System has been extended from construction to design [2]. This meant the shift from improving the productivity to improving the reliability of work flow [3]. There was a substantial influence of Toyota Production System and production theory of Lauri Koskela on this fact.

Since this time, the Last Planner System has been continuously evolving to finally achieve its current form. In the meantime, the Lean Construction Institute (LCI) has been founded in 1997 as a partnership between Gregory A. Howell and Glenn Ballard. The production theory of Koskela has been implemented and the work flow reliability improvement emphasized.

This Last Planner System tool enables for abandoning the concept of traditional approach towards realization of building projects and introduces the new type of thinking. However, to achieve a satisfactory result, one should implement the measures of the Last Planner System in an appropriate way.

* Corresponding author: j.roslon@ili.pw.edu.pl 
On the website of Lean Construction Institute, the following definition of the Last Planner System can be found [10]:

"Last Planner System - system for project production planning and control, aimed at creating a workflow that achieves reliable execution, developed by Glenn Ballard and Greg Howell, with documentation by Ballard in 2000. LPS is the collaborative, commitmentbased planning system that integrates should-can-will-did planning: pull planning, makeready look-ahead planning with constraint analysis, weekly work planning based upon reliable promises, and learning based upon analysis of PPC (Project Partnering Contracts) and Reasons for Variance".

\section{Last Planner System and traditional project control model}

Even though the Last Planner System has been developed for over twenty years already, it is still not well-known and properly understood in some parts of the engineering world. With its simple tools and new adaptations, it offers a perfect solution for the construction and design processes and enables project managers to improve the quality of their projects as well as satisfaction of the clients and owners.

Alan Mossman in his paper Last Planner: $5+1$ crucial \& collaborative conversations for predictable design \& construction delivery mentions eight exemplary reasons for adopting the Last Planner System in construction. These are [11]: to deliver projects more safely; to create a more predictable production program; to reduce project durations; to better manage costs; to reduce stress on project management staff; to help to improve the overall production process; to help to make projects a reliable customer for just-in-time deliveries; it works in a way that traditional Critical Path Methods (CPM) do not.

Traditional way of thinking in project management is based on establishing the sequence of tasks that should be done. In his paper, Ballard sharply criticized this kind of project control model. As he described, the traditional attitude is to control the objects such as time and resources. Controlling of resources consists in their efficient use $[8,9,12]$. This means, that appropriate productivity is set based on the budget that had been prepared for each resource. Taking into consideration the current state of the project, the forecast concerning the resources is made. Time controlling demands planning, scheduling and monitoring. The sequence and duration of activities is determined. Again, based on the progress of works and forecasts, the date of works completion can be estimated. As Ballard emphasized, the objective of time control is production or progress, not productivity [3]. In this philosophy, the focus is on taking actions in case any deviations from the targeted values (time and resources) occur. Quoting Diekmann and Thrush [4], "this (project control) system must provide the information needed for the project team and project participants to identify and correct problem areas and, ultimately, to keep project costs and schedule 'under control'".

The assumption of the pull strategy implemented in the Last Planner System is completely opposite. Pulling is a method of introducing materials or information into a production process. This way, from the list of the tasks that should be done, only those that can be done are chosen to be performed. Ballard mentions a very clear example of the activity that cannot be pushed - the concrete delivery on site. The material cannot be ordered long time before it is needed as it is not possible to estimate its amount and time of delivery of concrete in advance.

A traditional Push Planning System is presented in the Fig. 1. A Pull System of the Last Planner System is presented in the Fig. 2. The table 1 presents the comparison of CPM and the LPS. 


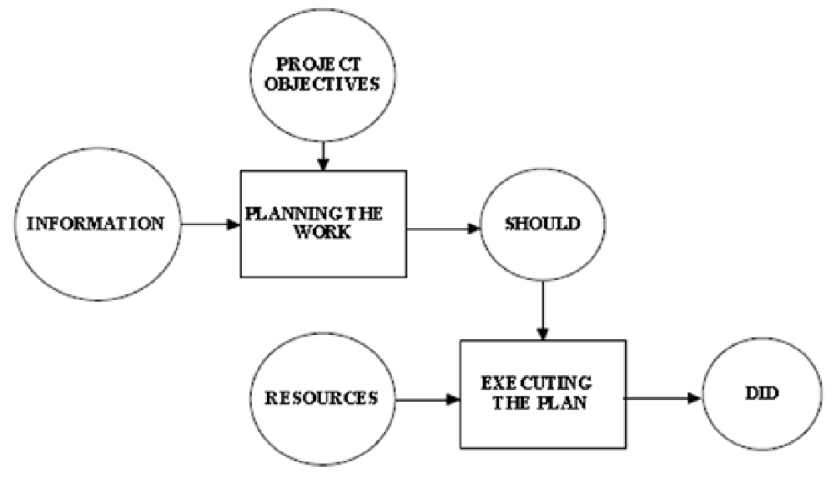

Fig.1. A traditional (Push) Planning System [3]

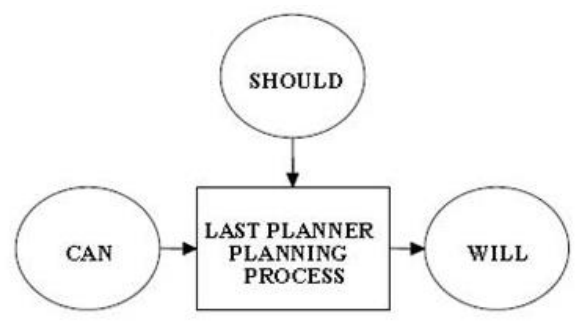

Fig. 2. Last Planner: A Pull System [3]

Table 1. Comparison of Critical Path Method and the Last Planner System, source: [1]

\begin{tabular}{|c|c|}
\hline Critical Path Method & Last Planner System \\
\hline CPM logic embedded in software & Applied common sense \\
\hline High maintenance & Low maintenance \\
\hline Managing Critical Path & Managing variability \\
\hline Focus on managing work dates & Focus on managing work flow \\
\hline Planning based on contracts & Planning based on interdependencies \\
\hline
\end{tabular}

The Critical Path Method has been developed in the late 1950 by the U.S. Navy as a mathematically based algorithm for scheduling a set of activities. It has been evolving to finally reach its current state to be widely implemented in scheduling of works in construction industry. Within CPM, the list of activities is prepared (so called Work Breakdown Structure), the duration of each task is determined and the dependencies between the activities established. In this method, the earliest possible start and finish dates as well as the latest ones are determined. The critical path is set - meaning the sequence of activities that in total gives the longest project duration. In case of any delay of any activity, the finish date of the entire project is shifted (the project is completed later). As Mossman notices [11], the Critical Path Method is a great tool to measure the feasibility of the project in terms of finishing the project according to a given schedule. However, the number of disadvantages of this method exists. 


\section{Summary}

The biggest disadvantage of CPM, comparing to the LPS is that in the first method, there is no way to determine which activities indeed can be done. As table 1 shows, the CPM logic is embedded in software and focuses on managing dates. The survey of Alan Mossman [11] showed that as many as 66\% UK projects in 2013 and $70 \%$ US projects in 2012 based on CPM were delivered late. According to the research of LPS developers, the following weak points of the Critical Path Method have been observed: all plans are forecasts; all forecasts are wrong, the longer the forecast, the more wrong it becomes, the more detailed the forecast, the more wrong it is. The results of aforementioned analysis show that the traditional system of project control is not valid and useful anymore. On the contrary, the Last Planner System applies the common sense in planning and focuses on the smooth work flow as well as takes into account the independencies between activities. This way, it helps to move from push to pull system and supports logistics planning involving much more just than the due dates and the sequence of prior tasks.

\section{References}

1. R.F. Aziz, \& S. M. Hafez, Alexandria Engineering Journal, 52(4), 679-695 (2013)

2. G. Ballard, G. Howell, Implementing lean construction: improving downstream performance. Lean construction, 111-125 (1997)

3. H. G. Ballard, The last planner system of production control (Doctoral dissertation, The University of Birmingham 2000).

4. J.E. Diekmann, K.B. Thrush, K. B. Project control in design engineering. Construction Industry Institute, University of Texas at Austin (1986)

5. N. Ibadov, J. Rosłon,. Archives of Civil Engineering, 61(3), 105-118 (2015)

6. M. Krzemiński, M. Książek, Warsztaty Inżynierów Budownictwa,,Problemy przygotowania i realizacji inwestycji budowlanych”, 249-254 (Puławy 2008),

7. M. Książek, P. Nowak, J. Rosłon, T. Wieczorek, Procedia Engineering, 91, 406-411 (2014)

8. M.V. Książek, P.O. Nowak, S. Kivrak, J.H. Rosłon, L. Ustinovichius, Journal of civil engineering and management, 21(2), 248-259 (2015)

9. M. Książek, P. Nowak, Logistyka, 6 (2009)

10. Materials presented on the website of Lean Construction Institute: www.leanconstruction.org

11. A. Mossman, Last Planner $\mathbb{R}$ : $5+1$ crucial \& collaborative conversations for predictable design \& construction delivery. The Change Business Ltd., UK, 26 (2013).

12. L. Ustinovichius, E. Zavadskas, D. Migilinskas, A. Malewska, P. Nowak, A. Minasowicz, (2006, September). In International Conference on Cooperative Design, Visualization and Engineering, 295-302 (Springer Berlin Heidelberg, 2006),

13. M. Kaftanowicz, M. Krzemiński, Procedia Engineering, 111, 364-370 (2015)

14. B. Jankowski, J. Prokocki, M. Krzemiński, Procedia Engineering 111, 351-355 (2015)

15. E. Radziszewska-Zielina, ACE 62(2), 167 (2016)

16. E. Radziszewska-Zielina, G. Śladowski, Journal of Cultural Heritage (2017) 